\title{
MINIMIZING STRAWBERRY MINERAL FERTILIZATION AND ENHANCING WATER USE EFFICIENCY USING MAGNETIZED IRRIGATION WATER
}

Amany A. Abd El-Latif ${ }^{1}$; A.A. Abdelshafy ${ }^{1}$ and T.A. Eid ${ }^{2}$ 1- Potato and Vegetatively Propagated Crops Dept., Hort. Res. Inst., ARC Giza.

2- Soil, Water and Environment Res. Inst., ARC Giza.

\begin{abstract}
This study was carried out at Al-Kanater Research Station, El-Kaluobia Governorate during the two successive seasons of 2012-2013 and 2013-2014, to investigate the effect of magnetized water on minimizing strawberry mineral fertilization. Four treatments were used i.e., tap water plus $100 \%$ NPK (control), magnetized water plus $50 \% \mathrm{NPK}$, magnetized water plus $75 \% \mathrm{NPK}$ and magnetized water plus $100 \%$ NPK of the recommended mineral fertilization rates. Data were recorded on some vegetative growth characters, early and total fruit yield, some physical and chemical fruit quality parameters and macro and micro elements in leaves. Results indicated that irrigation with magnetized water plus $50 \%$ NPK of the recommended fertilization rate showed the highest values of total chlorophyll, total carbohydrates, early and total yield, fruit firmness, total soluble solids in fruits and water use efficiency as compared with control. Moreover, magnetized water plus $75 \%$ NPK of the recommended rate of mineral fertilization showed the highest values of NPK and manganese contents. In general ascorbic acid was decreased by using magnetized water. The study recommend using $50 \%$ of the recommended NPK fertilization rates plus magnetized water to increase yield and quality of strawberry.

Keywords: Strawberry, magnetized water, mineral fertilization rates, yield and fruit quality, water use efficiency.
\end{abstract}

\section{INTRODUCTION}

Strawberry is one of the most important crops in Egypt. Reducing chemical fertilizers used in strawberry fields is very needed to reduce production cost, environmental pollution and suitable for human health. One of the new strategies to reduce consumption of chemical fertilizers is using magnetized water technology in irrigation.

Magnetic treatment has reportedly shown various benefits to soil which can improve the water consumption, crop yields and plant growth. The three main functions of magnetic treated water in soil are removal of excess soluble salts, lowering $\mathrm{pH}$ values of soil layers, and dissolving slightly soluble components such as phosphates carbonates and sulfates as found by Hilal and Hilal (2000), Esitken and Turan (2004) and Mohamed and Ebead (2013). Furthermore, magnetic treated water increases nutrient mobility in soil and enhances extraction and uptake of NPK and Fe by plants. Also increases the efficiency of added fertilizers (Hajer et al., 2006). Magnetic treatment of water increases the water absorption in soil. Furthermore, magnetic treatment of saline irrigation water is reportedly an effective method for soil desalination. Moreover, leaching the soil with magnetic water (MW) significantly increases 
available soil phosphorus content compared with the leaching with normal water at all soil depths. Behavior of nutrients under magnetic field (MF) is a function of their magnetic susceptibility as reported by Hilal and Hilal (2000).

Magnetic water treatment was used to enhance growth, chemical constituents and productivity of chickpea Hozayn et al. and Abdul Qados (2010). Using magnetic irrigation water gave taller and heavier plants, increased the contents of $\mathrm{P}$ in plant and soil, Ec value and total yield while reduced $\mathrm{pH}$ value of soil extraction and did not affect $\mathrm{Na}$ concentration in tomato plants as mentioned by Abou El-Yazied et al. (2012). Also, Maheshwari and Grewal (2009) mentioned that magnetic treatment of irrigation water increased significantly plant yield of snow pea and celery and reduced soil $\mathrm{pH}$ after plant harvesting. The use of magnetized water can led to improvement of quantity and quality on common bean as reported by Moussa (2011) who mentioned that magnetic water could stimulate plant defense system, photosynthetic activity and translocation efficiency of photo assimilates in common bean plants. Also, Hameda (2014) found that irrigating the plants with magnetic water increased significantly plant height, total chlorophyll, total carbohydrates and yield productivity compared to control treatments (Tap water), and the use of magnetic water exhibited an increase in potassium, calcium and phosphorus content in all plant parts.

Many scientists reported that water use efficiency was increased by using magnetized water in irrigation as mentioned by Mahdi (2011) on corn, Hozayn et al. (2013) on sugar beet.

Therefore, the present work was conducted to study the effect of irrigation with magnetized water on minimizing strawberry mineral fertilization rates.

\section{MATERIALS AND METHODS}

This experiment was carried out during the two successive seasons of 2012/2013 and 2013/2014 at Horticulture Research Station, Al-Qanater AlKhairya, Qalubiya Governorate to investigate the impact of magnetized water application for reducing the use of mineral fertilization and improving growth, yield and quality as well as water use efficiency of strawberry cultivated with Frigo (cold stored) transplants cv. Festival. Soil type was clay loam with $\mathrm{pH}$ of 7.40 and EC of 1.10 the soil analysis of the experiment was shown in Table (1).

Plants were transplanted on $16^{\text {th }}$ and $15^{\text {th }}$ of September in the two tested seasons respectively on beds with 25 meters length, $120 \mathrm{~cm}$ width, 40 $\mathrm{cm}$ height and $50 \mathrm{~cm}$ between beds. The distances between plants were 25 $\mathrm{cm}$, and $30 \mathrm{~cm}$ between the rows (four rows were planted on the bed). Drip irrigation was used by drippers $(4 \mathrm{l} / \mathrm{h}$.) using under ground well water with EC of 320 . Each replicate consisted of 3 beds with its respective water valve to provide easy access for fertilizer concentration. One bed was left for separation between each two replicates. The used treatments were four i.e., $100 \%, 75 \%$, and $50 \%$ of NPK (120:80:160 unit/feddan), respectively as recommended by Ministry of Agriculture for the commercial production of strawberry under Egyptian conditions, and control treatment (100\% of NPK 
plus tap water). Treatments were arranged in complete randomized block design with three replicates.

Table (1): Chemical and physical analysis of the experimental site.

\begin{tabular}{|c|c|c|c|c|}
\hline \multirow{3}{*}{ Parameter } & \multicolumn{4}{|c|}{ Value } \\
\hline & \multirow{2}{*}{\begin{tabular}{|c|} 
Tap water \\
Control \\
\end{tabular}} & \multicolumn{3}{|c|}{ Magnetized Water } \\
\hline & & $100 \%$ NPK & $75 \%$ NPK & $50 \%$ NPK \\
\hline $\mathrm{pH}$ (1: $2.5 \mathrm{w} / \mathrm{v}$ soil water suspension) & 7.34 & 7.24 & 7.38 & 7.43 \\
\hline EC $(\mathrm{dS} / \mathrm{m}$, soil paste extract & 1.98 & 1.37 & 1.25 & 1.11 \\
\hline \multicolumn{5}{|c|}{ Cations and anions in soil paste extract (mmolc/L): } \\
\hline $\mathrm{CO}_{3}{ }^{=}$ & 0.00 & 0.00 & 0.00 & 0.00 \\
\hline $\mathrm{HCO}_{3}^{-}$ & 2.00 & 2.10 & 2.30 & 2.20 \\
\hline $\mathrm{Cl}^{-}$ & 16.60 & 9.50 & 7.90 & 7.20 \\
\hline $\mathrm{SO}_{4}=$ & 3.40 & 1.40 & 1.80 & 1.60 \\
\hline $\mathrm{Ca}^{++}$ & 5.11 & 2.75 & 2.41 & 2.11 \\
\hline $\mathrm{Mg}++$ & 6.71 & 2.40 & 1.10 & 0.90 \\
\hline $\mathrm{Na}^{+}$ & 10.18 & 7.85 & 8.49 & 7.99 \\
\hline $\mathrm{K}^{+}$ & 0.41 & 0.35 & 0.31 & 0.29 \\
\hline Parameter & \multicolumn{4}{|c|}{ Value } \\
\hline \multicolumn{5}{|c|}{ Particle size distribution (\%): } \\
\hline Clay & \multicolumn{4}{|c|}{31.40} \\
\hline Silt & \multicolumn{4}{|c|}{33.50} \\
\hline Fine sand & \multicolumn{4}{|c|}{34.00} \\
\hline Coarse sand & \multicolumn{4}{|c|}{1.10} \\
\hline Texture class & \multicolumn{4}{|c|}{ Clay loam } \\
\hline
\end{tabular}

Irrigation water passed through a magnetic device (model Magnetto, made in USA) which pinned to the main irrigating water line after the fertilizer injector. The device comprised of two magnets, arranged to the north and south poles. The directions of magnetic field generated at the flow rate diameter 2 inch and were arranged in a way to get the technological magnetic forces is (28 gauss) as shown in (Fig. 1).

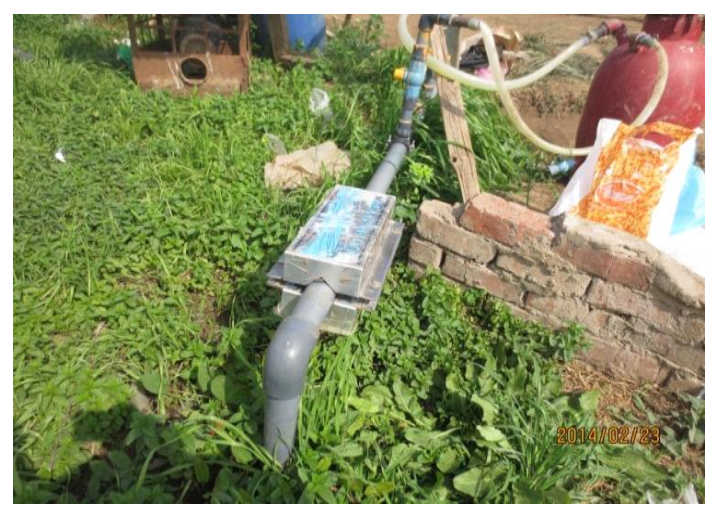

The fertilization was taken place after 10 days from planting date and it was added twice weekly at winter then three times weekly during spring and early summer. 


\section{Data recorded:}

Vegetative growth characteristics.

Ten plants were randomly chosen from each experimental plot as a representative sample on February $1^{\text {st }}$ after 130 days from transplanting and the following data were recorded.

1- Plant length and number of leaves/plant. Minolta chlorophyll meter, SPAD502 , was used to determine the total chlorophyll.

2- Total nitrogen, phosphorus and potassium were determined in the digested dry matter of plant leaves according to the methods described by Pregl (1945), Trough and Meyer (1939) and Chapman and Pratt (1961), respectively

3- The microelements $(\mathrm{Fe}, \mathrm{Zn}, \mathrm{Mn}$, and $\mathrm{Cu}$ ) were determined as mentioned by Cottenie et al. (1982)

4- Total carbohydrates: It was determined colorimetrically according to the method described by James (1995).

5- Fruit yield and its components:

A. Early yield: It was determined by using plot yield, determined from all plants in plot area during November, December and January and early yield as $\mathrm{g} / \mathrm{plant}$ and ton/fed were calculated.

B. Total yield: It was determined by using plot yield, calculated from all plants in plot area all over the season and total yield as $\mathrm{g} / \mathrm{plant}$ and ton/fed were calculated.

Physical and chemical fruit quality:

Random samples of 10 fruits at ripe stage from each experimental plot were taken to determine the following:-

* Fruit firmness, It was determined as $\left(\mathrm{kg} / \mathrm{cm}^{2}\right)$ by using a Chatillon penetometer (N.Y., U.S.A) Gauje-R with a needle $0.4 \mathrm{~mm}$ in diameter.

* Total soluble solids (TSS) percentage, were determined by using hand refractometer model (ATAGO N-20E).

* Total titratable acidity and ascorbic acid were determined as the method described in A. O. A.C. (1990).

- Water Use Efficiency (WUE): It was determined according to Jensen (1983). The following equation was used as follow.

$$
\text { WUE }=\frac{\text { Fruit yield }(\mathrm{kg} / \mathrm{fed} .)}{\text { Total seasonal applied water }\left(\mathrm{m}^{3} / \mathrm{fed} .\right)}
$$

\section{Statistical analysis:}

Data were statistically analyzed according to the analysis of variance as described by Waller and Duncan (1969).

\section{RESULTS AND DISCUSSION}

\section{Vegetative growth:}

Data shown in Table (2) declared that utilization of magnetized water plus $100 \%$ of NPK gave significant increment in strawberry number of leaves when compared with control in both tested seasons, also, data declared that 
there is no significant differences between $100 \%, 75 \%$ and $50 \%$ NPK under presence of magnetized water in the first season. While tap water plus $100 \%$ NPK gave the lowest values of number of leaves per plant in the first and second tested seasons. Moreover data showed that using magnetized water plus $100 \%$ and $75 \%$ NPK in the first second seasons respectively as compared with tap water plus $100 \%$ NPK (control).

Although there is no any significant differences between magnetized water plus all rates of NPK in the first season comparing with control treatment, the magnetized water plus $75 \%$ NPK was the only treatment increased significantly plant height as compared with control in the second season. On the other hand, control treatment gave low values of plant height in both tested seasons without any significant differences as compared with magnetized water plus $100 \%$ NPK in the second season which record the lowest value.

Concerning strawberry leaves total chlorophyll, data in Table (2) observed that using magnetized water plus $50 \%$ NPK in the first season and plus $75 \%$ NPK in second season increased significantly total chlorophyll as compared with control. Also, tap water gave the lowest values in both tested seasons. Moreover, there is no any significant differences between magnetized water plus 100 and $75 \%$ NPK in the second season.

Table (2): Effect of magnetized water and mineral fertilization rates on number of leaves, plant height and total chlorophyll of strawberry during $2012 / 2013$ and $2013 / 2014$ seasons.

\begin{tabular}{|l|c|c|c|}
\hline Treatments & $\begin{array}{c}\text { No. of leaves } \\
\text { per plant }\end{array}$ & $\begin{array}{c}\text { Plant height } \\
\text { (cm) }\end{array}$ & $\begin{array}{c}\text { Total Chlorophyll } \\
\text { (mg/100g FW) }\end{array}$ \\
\hline \multicolumn{4}{|c|}{$1^{\text {st }}$ season } \\
\hline MW + $100 \%$ NPK & $26.00 \mathrm{a}$ & $19.33 \mathrm{a}$ & $46.13 \mathrm{c}$ \\
\hline $\mathrm{MW}+75 \% \mathrm{NPK}$ & $25.00 \mathrm{a}$ & $19.00 \mathrm{a}$ & $48.10 \mathrm{~b}$ \\
\hline $\mathrm{MW}+50 \% \mathrm{NPK}$ & $24.33 \mathrm{ab}$ & $18.33 \mathrm{a}$ & $49.57 \mathrm{a}$ \\
\hline Tap water + 100 \% NPK (control) & $22.67 \mathrm{~b}$ & $15.33 \mathrm{~b}$ & $44.67 \mathrm{~d}$ \\
\hline \multicolumn{4}{|c|}{$2^{\text {nd }}$ season } \\
\hline MW + 100 \% NPK & $24.00 \mathrm{a}$ & $21.67 \mathrm{c}$ & $51.53 \mathrm{a}$ \\
\hline MW + 75 \% NPK & $20.92 \mathrm{~b}$ & $25.33 \mathrm{a}$ & $51.67 \mathrm{a}$ \\
\hline MW + 50 \% NPK & $21.17 \mathrm{~b}$ & $24.00 \mathrm{~b}$ & $47.82 \mathrm{~b}$ \\
\hline Tap water + 100 \% NPK (control) & $20.83 \mathrm{~b}$ & $22.67 \mathrm{c}$ & $46.10 \mathrm{c}$ \\
\hline
\end{tabular}

\section{MW=Magnetized water}

Values within the same column followed by the same small or capital letter(s) do not significantly differ from each other according to Duncan's multiple range test at $5 \%$ level.

These results are in the agreement with those of Aladjadjiyan (2002). Morejon et al. (2007), Al-Shrouf (2014), Hameda (2014) and Mrunal (2014).

The positive effects of magnetized water on number of leaves is very important since they appear to induce an improved capacity for nutrients, photosynthesis and water uptake providing greater physical support to the plant (Sadeghipour and Aghaei, 2013).

Data from Table (2) also indicated that total chlorophyll of strawberry leaves increased significantly due to the irrigation with magnetic water in 
combined with $50 \%$ of recommended NPK in the first season as compared with control, while in the second season magnetic water with the use of $75 \%$ of recommended NPK gave the highest significant value of total leaf chlorophyll comparing with the tap water. This increment of photosynthetic pigments are in the line with Mulook et al. (2011), who refers the chlorophyll increment to the increment of Relative Water Content (RWC) in plant due to irrigation with magnetized water. This RWC is the appropriate measure of plant water status in the terms of the physiological consequence of cellular water deficit Basant et al. (2007). The ability of plants treated with magnetic water to have high content of total chlorophyll under water stress is considered a benefit point for plants. Khazan and Abdullatif (2009) attributed the increase of total chlorophyll to the decrease of the amount of manganese in treated plants compared to normal water. Similarly, the shortage in chlorophyll amount under the environmental stress is due to manganese toxicity which leads to a lack of chlorophyll between the veins of leaves which leading to a decrease of photosynthesis as a whole.

\section{Early and total yield:}

As for strawberry yield, data from Table (3) described that utilizing magnetized water plus $100 \%$ NPK in the first season and plus $50 \%$ NPK in the second season increased significantly early and total yield as compared with tap water plus 100\% NPK (control) which record the lowest values in the two tested seasons.

Table (3): Effect of magnetized water and mineral fertilization rates on early and total yield of strawberry during 2012/2013 and 2013/2014 seasons.

\begin{tabular}{|c|c|c|c|c|}
\hline Treatments & $\mid \begin{array}{c}\text { Early yield } \\
\text { g/plant }\end{array}$ & $\begin{array}{c}\text { Early yield } \\
\text { ton/Fed. }\end{array}$ & $\begin{array}{c}\text { Total yield } \\
\text { g/plant }\end{array}$ & $\begin{array}{c}\text { Total } \\
\text { yield } \\
\text { ton/fed. }\end{array}$ \\
\hline \multicolumn{5}{|c|}{ 1st season } \\
\hline $\mathrm{MW}+100 \% \mathrm{NPK}$ & $0.153 a$ & $5.52 a$ & $0.587 a$ & $23.47 a$ \\
\hline $\mathrm{MW}+75 \% \mathrm{NPK}$ & $0.112 b$ & $4.48 b$ & $0.530 \mathrm{~b}$ & $21.19 b$ \\
\hline $\mathrm{MW}+50 \% \mathrm{NPK}$ & $0.136 a$ & $5.43 a$ & $0.570 \mathrm{a}$ & $22.88 a$ \\
\hline Tap water + $100 \%$ NPK (control) & $0.089 \mathrm{c}$ & $3.57 c$ & $0.494 \mathrm{c}$ & $19.77 c$ \\
\hline \multicolumn{5}{|c|}{ 2nd season } \\
\hline $\mathrm{MW}+100 \% \mathrm{NPK}$ & $0.147 a b$ & $5.87 b$ & $0.576 b$ & $23.05 b$ \\
\hline $\mathrm{MW}+75 \% \mathrm{NPK}$ & $0.139 b$ & $5.55 c$ & $0.554 b$ & $22.17 c$ \\
\hline $\mathrm{MW}+50 \% \mathrm{NPK}$ & $0.159 a$ & $6.37 a$ & $0.608 \mathrm{a}$ & $24.31 a$ \\
\hline Tap water + $100 \%$ NPK (control) & $0.104 \mathrm{c}$ & $4.16 \mathrm{~d}$ & $0.493 \mathrm{c}$ & $19.73 d$ \\
\hline
\end{tabular}

\section{MW=Magnetized water}

Values within the same column followed by the same small or capital letter(s) do not significantly differ from each other according to Duncan's multiple range test at $5 \%$ level.

These results confirm those of Hozayn et al. (2010), Abou El-Yazied et al. (2012) and Al-Shrouf (2014) who recorded yield increments in legumes, tomatoes and wheat respectively by using magnetized water compared with control. These results may be due to that magnetized water influenced adsorption of $\mathrm{P}$ and $\mathrm{K}$ from soil and thus increasing it's availability to plants 
which resulted in enhancing plant growth and productivity as mentioned by Basant and Harsharn (2009).

Fruit chemical characteristics:-

Data from Table (4) presented that total soluble solids percentage of strawberry fruit was increased significantly by using magnetized water plus any rate of NPK in the first season as compared with control, while in the

Table (4): Effect of magnetized water and mineral fertilization rates on total carbohydrates and some fruit characteristics of strawberry fruits during $2012 / 2013$ and $2013 / 2014$ seasons.

\begin{tabular}{|c|c|c|c|c|c|}
\hline Treatments & $\begin{array}{l}\text { TSS } \\
(\%)\end{array}$ & $\begin{array}{c}\text { Acidity } \\
\text { (mg/100gf.w) }\end{array}$ & $\begin{array}{l}\text { Carbohydrates } \\
\text { (g/100g d.w) }\end{array}$ & $\begin{array}{l}\text { Ascorbic acid } \\
\text { (mg/100gf.w) }\end{array}$ & $\begin{array}{l}\text { Firmness } \\
\text { (g/cm2) }\end{array}$ \\
\hline \multicolumn{6}{|c|}{ 1st season } \\
\hline $\mathrm{MW}+100 \% \mathrm{NPK}$ & $8.13 a$ & $0.46 a b$ & $1.27 a b$ & $30.36 c$ & $263.7 b$ \\
\hline $\mathrm{MW}+75 \% \mathrm{NPK}$ & $8.30 a$ & $0.50 a$ & $1.05 b$ & $33.03 b$ & $255.3 c$ \\
\hline $\mathrm{MW}+50 \% \mathrm{NPK}$ & $8.27 a$ & $0.40 \mathrm{~b}$ & $1.53 a$ & $27.74 d$ & $277.7 a$ \\
\hline $\begin{array}{l}\text { Tap water }+100 \% \\
\text { NPK (control) }\end{array}$ & $6.83 b$ & $0.41 b$ & $1.11 b$ & $40.20 a$ & $216.7 d$ \\
\hline \multicolumn{6}{|c|}{ 2nd season } \\
\hline $\mathrm{MW}+100 \% \mathrm{NPK}$ & $6.57 \mathrm{~b}$ & $0.50 a b$ & $1.22 b$ & $29.05 c$ & $260.7 b$ \\
\hline $\mathrm{MW}+75 \% \mathrm{NPK}$ & $6.80 a b$ & $0.55 a$ & $1.27 a b$ & $38.40 \mathrm{~b}$ & $252.7 c$ \\
\hline $\mathrm{MW}+50 \% \mathrm{NPK}$ & $7.07 a$ & $0.44 c$ & $1.46 a$ & $28.57 \mathrm{c}$ & $280.3 a$ \\
\hline $\begin{array}{l}\text { Tap water }+100 \% \\
\text { NPK (control) }\end{array}$ & $6.60 \mathrm{~b}$ & $0.45 b c$ & $1.23 b$ & $40.25 a$ & 222.3d \\
\hline
\end{tabular}

MW=Magnetized water

Values within the same column followed by the same small or capital letter(s) do not significantly differ from each other according to Duncan's multiple range test at $5 \%$ level.

Second season magnetized water plus 50\% NPK increased significantly fruit TSS when compared with control.

Strawberry fruit acidity was increased significantly by using magnetized water plus $75 \%$ NPK in both tested seasons comparing with tap water plus $100 \%$ NPK. On the other hand, magnetized water plus 50\% NPK gave the lowest values in the tested seasons as compared with control.

Concerning ascorbic acid content in strawberry fruits, data from Table (4) referred the high significant increment in ascorbic acid to the tap water plus $100 \%$ NPK in both seasons as compared with all rates of NPK when using magnetized water. Also, fruit firmness increased significantly by using magnetized water plus 50\% NPK as compared with control in the two tested seasons.

The results of carbohydrates were in the agreement with Hameda (2014) who reported that irrigated plants with magnetic water increased significantly total available carbohydrates as compared with tap water because the close relationship between stomatal conductance and photosynthesis. Also, the increment in TSS, total acidity and firmness was due to utilization of magnetized water which stimulates plant defense system, photosynthetic activity and translocation efficiency of photo assimilates in plants as reported by Helal (2011). 


\section{Mineral contents of leaves:}

Macro mineral contents of strawberry leaves from Table (5) declared that magnetized water plus $75 \%$ NPK increased significantly the leaves contents of nitrogen, phosphorus and potassium in the two tested seasons as compared with tap water plus $100 \%$ NPK which viewed the lowest values.

Table (5): Effect of magnetized water and mineral fertilization rates on some macro elements of strawberry leaves during 2012/2013 and $2013 / 2014$ seasons.

\begin{tabular}{|c|c|c|c|}
\hline Treatments & $\mathbf{N}(\%)$ & $\mathbf{P}(\%)$ & K (\%) \\
\hline \multicolumn{4}{|c|}{ 1st season } \\
\hline $\mathrm{MW}+100 \% \mathrm{NPK}$ & $2.58 b$ & $0.433 b$ & $0.960 \mathrm{~b}$ \\
\hline $\mathrm{MW}+75 \% \mathrm{NPK}$ & $3.35 a$ & $0.495 a$ & $1.04 \mathrm{a}$ \\
\hline $\mathrm{MW}+50 \% \mathrm{NPK}$ & $2.28 \mathrm{bc}$ & $0.402 \mathrm{c}$ & $0.869 \mathrm{c}$ \\
\hline Tap water + $100 \%$ NPK (control) & $2.07 c$ & $0.360 d$ & $1.009 a b$ \\
\hline \multicolumn{4}{|c|}{ 2nd season } \\
\hline $\mathrm{MW}+100 \% \mathrm{NPK}$ & $2.50 \mathrm{~b}$ & $0.448 \mathrm{a}$ & $0.931 b$ \\
\hline $\mathrm{MW}+75 \% \mathrm{NPK}$ & $3.33 a$ & $0.467 a$ & $1.009 a$ \\
\hline $\mathrm{MW}+50 \% \mathrm{NPK}$ & $2.32 b$ & $0.423 b$ & $0.883 b$ \\
\hline Tap water + $100 \%$ NPK (control) & $1.75 c$ & $0.342 \mathrm{c}$ & $0.946 a b$ \\
\hline
\end{tabular}

\section{MW=Magnetized water}

Values within the same column followed by the same small or capital letter(s) do not significantly differ from each other according to Duncan's multiple range test at $5 \%$ level.

This increase could be due to the increase of membrane permeability by magnetized water as reported by Esitken and Turan (2004) on strawberry and Dhawi et al. (2009) on date palm seedlings.

The present data from Table (6) showed that utilizing magnetized water plus $100 \%$ NPK didn't differ significantly than control treatment in the leaves Fe contents in the first season, while in the second season magnetized water plus $75 \%$ NPK increased significantly leaves Fe content comparing with control.

Also data showed that, leaves $\mathrm{Zn}$ contents increased significantly than control by using magnetized water plus $100 \%$ and $50 \%$ NPK in the first season and magnetized water plus $50 \% \mathrm{NPK}$ in the second season.

Concerning leaves content of $\mathrm{Mn}$ data declared that utilizing magnetized water plus $75 \%$ NPK increased significantly leaves manganese contents in both tested seasons as compared with control. Meanwhile, there is no any significant differences between magnetized water plus $100 \%$ and $75 \%$ in the second season.

Data in Table (6) confirmed that magnetized water plus $75 \%$ and $50 \%$ NPK in the first and second seasons respectively increased significantly strawberry leaves content of cupper comparing to tap water plus $100 \%$ NPK. 
Table (6): Effect of magnetized water and mineral fertilization rates on some micro elements of strawberry leaves during 2012/2013 and 2013/2014 seasons.

\begin{tabular}{|l|l|l|l|c|}
\hline Treatments & Fe (ppm) & Zn (ppm) & Mn (ppm) & Cu (ppm) \\
\hline \multicolumn{4}{|c|}{ 1st season } \\
\hline MW + 100 \% NPK & $30.93 \mathrm{a}$ & $16.50 \mathrm{a}$ & $22.33 \mathrm{c}$ & $5.17 \mathrm{~d}$ \\
\hline MW + 75\% NPK & $24.48 \mathrm{~b}$ & $14.67 \mathrm{~b}$ & $28.23 \mathrm{a}$ & $28.50 \mathrm{a}$ \\
\hline MW + 50 \% NPK & $24.63 \mathrm{~b}$ & $16.17 \mathrm{a}$ & $26.07 \mathrm{~b}$ & $12.63 \mathrm{~b}$ \\
\hline $\begin{array}{l}\text { Tap water + 100 \% NPK } \\
\text { (control) }\end{array}$ & $31.15 \mathrm{a}$ & $12.75 \mathrm{c}$ & $27.17 \mathrm{ab}$ & $8.67 \mathrm{c}$ \\
\hline \multicolumn{5}{|l|}{ 2nd season } \\
\hline MW + 100 \% NPK & 23.72c & $15.00 \mathrm{~b}$ & $28.53 \mathrm{a}$ & $4.00 \mathrm{c}$ \\
\hline MW + 75\% NPK & $30.97 \mathrm{a}$ & $13.83 \mathrm{~b}$ & $28.27 \mathrm{a}$ & $5.67 \mathrm{c}$ \\
\hline MW + 50 \% NPK & $18.28 \mathrm{~d}$ & $17.25 \mathrm{a}$ & $25.47 \mathrm{~b}$ & $11.25 \mathrm{a}$ \\
\hline $\begin{array}{l}\text { Tap water + 100 \% NPK } \\
\text { (control) }\end{array}$ & $28.07 \mathrm{~b}$ & $12.33 \mathrm{c}$ & $24.17 \mathrm{~b}$ & $7.80 \mathrm{~b}$ \\
\hline
\end{tabular}

MW=Magnetized water

Values within the same column followed by the same small or capital letter(s) do not significantly differ from each other according to Duncan's multiple range test at $5 \%$ level.

These results are in the same line with those of Estiken and Turan (2004) on strawberry, Dhawi et al. (2009) on date palm. The functions of magnetic water in soil are lowering $\mathrm{pH}$ values of soil layers, dissolving slightly soluble components as mentioned by Hilal and Hilal (2000), Estiken and Turan (2004) and Mohamed and Ebead (2013) and Hajer et al. (2006) who recorded increases in nutrient mobility and enhancement the uptake of $\mathrm{N}, \mathrm{P}, \mathrm{K}$ and $\mathrm{Fe}$ by plants when using magnetized water and increase the efficiency of added fertilizers. Also, magnetic water has been reported to affect macromolecules uptake, the accumulation of the elements in each plant and in the same plant different parts which led to a noticeable increases content of $\mathrm{Mg}, \mathrm{Fe}$ and $\mathrm{Cu}$ in grain and $\mathrm{P}, \mathrm{Ca}, \mathrm{K}$ and $\mathrm{Zn}$, also the magnetic water increased ions content significantly with prolonged exposure treatment may irreversibly affect cell membrane permeability leading to increase element uptake as mentioned by Dhawi (2014).

Water use efficiency (WUE):

In Fig. (2) results indicated that, decreasing the amounts of NPK fertilization rates $(50 \%)$ of recommended dose of NPK combined with magnetized water led to an increase in water use efficiency values followed by $100 \%$ then $75 \%$ dose of NPK. Control treatment gave the lowest values.

Average water use efficiency values in 2012/2013 were 10.03, 9.10, 9.78, and $8.45 \mathrm{~kg}$ fruit $/ \mathrm{m}^{3}$ for the 100,75 and $50 \%$ dose of NPK and control, respectively. While respective values in 2013/2014 were 9.94, 9.26, 10.10 and $8.44 \mathrm{~kg}$ fruit $/ \mathrm{m}^{3}$, respectively. 

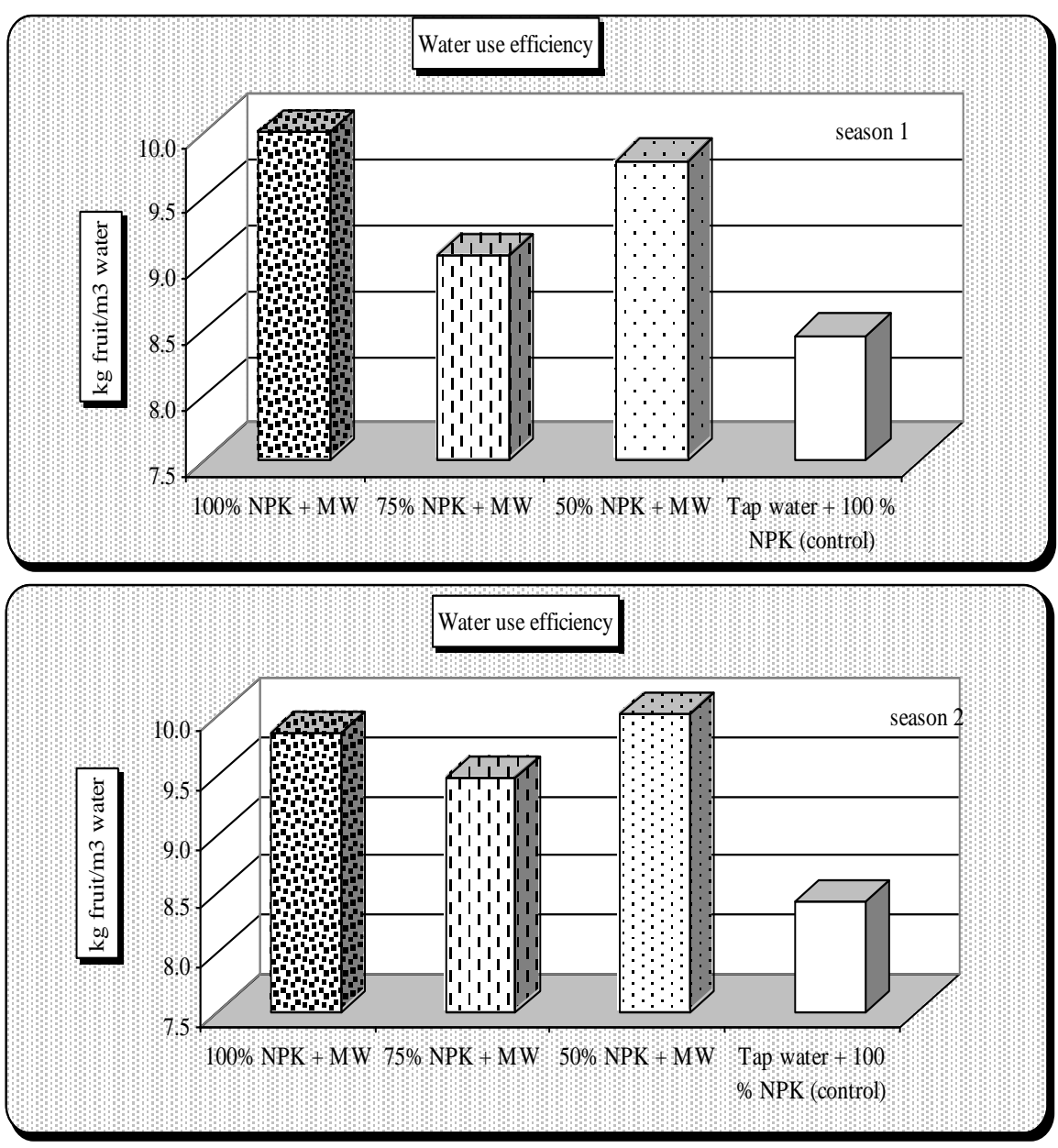

MW=Magnetized water

Fig. (2). Effect of magnetized water and mineral fertilization rate on Water use efficiency $\left(\mathrm{kg} / \mathrm{m}^{3}\right.$ water) of strawberry during 2012/2013 and 2013/2014 seasons.

Thus magnetic water application with 100, 75 and $50 \%$ dose of NPK gave increases of $17.8,9.8$ and $19.5 \%$, respectively over control averages of the two seasons. Magnetic treatment of water has been reported to change some of the physical and chemical properties of water, mainly hydrogen bonding, polarity, surface tension, conductivity, $\mathrm{pH}$ and solubility of salts (Amiri and Dadkhah, 2006; Ozeki and Otsuka, 2006). These changes in water properties may be capable of affecting the growth of plants. Mulook et al. (2011) recorded that irrigation of plants with magnetized water led to increase water use efficiency under normal and drought water stress as 
compared to the recommended irrigation. Magnetic treatment of irrigation water is an acknowledged technique for achieving high water use efficiencies due to its effect on some physical and chemical properties of water and soil (Basant et al., 2007 and Maheshwari and Grewal, 2009). These changes resulted in an increased ability of soil to get rid of salts and consequently better assimilation of nutrients and fertilizers in plants during the vegetative stage. Osman et al. (2014) concluded that the magnetic water technique led to improve crop yield productivity, providing greater physical support to the developing shoot, better root growth and development.

\section{REFERENCES}

Abou El-Yazied, A., A. M. El-Gizawy, S. M. Khalf, A. ElSatar and O. A. Shalaby (2012). Effect of magnetic field treatments for seeds and irrigation water as well as $\mathrm{N}, \mathrm{P}$ and $\mathrm{K}$ levels on productivity of tomato plants. J. of applied Sciences Research, 8 (4): 2088-2099.

Aladjadjiyan A. (2002). Study of the influence of magnetic field on some biological characteristics of Zea maiz. J. of Centr. Eur. Agric., 3 (2): 89-94.

Al-Shrouf, A. M. (2014). The effect of magnetic treatment of irrigation water on cucumber production and water productivity. International Conf. on Agri. Eng. Acta Hort., 1054. ISHS.2014.

Amiri, M.C. and A.A. Dadkhah (2006). On reduction in the surface tension of water due to magnetic treatment Colloids Surf. A: Phys. Eng. Asp., 278 (1-3): 252-255.

A.O.A.C. (1990). Official and Tentative methods of analysis. Association of Official Analytical Chemists. Washington, D.C, U.S.A.

Basant L. Maheshwari and Harsharn S. Grewal (2009). Magnetic treatment of irrigation water: Its effects on vegetable crop yield and

water productivity. Agric. Water Man., 96: 1229-1236.

Basant, M., S. Bunce and G. Harshan (2007). Irrigation and water saving potential of magnetic treated water in vegetable crops. Research Direction Office of Research Services, Sydney, Australia, pp: 12-22.

Chapman, H.D. and P.F. Pratt (1961). Methods of Analysis for Soils; Plants and Waters. Div. Agric. Sci. Univ. Calif., Berkeley PP. 309.

Cottenie, G. Verlo, L. Kiekeus, G.Velghe and R. Camerlynck (1982). Chemical Analysis of plants and Soils. Lab. Anal. and Agrochemistry State Univ., Ghent, Belgium.

Dhawi, F. (2014). Why magnetic fields are used to enhance a plants growth and productivity? Annual Research \&review in Biology.,4(6): 886-896.

Dhawi, F., Al-Khayri, J.M., and H. Essam (2009). Static magnetic field influence on elements composition in date palm (Phoenix dactylifera L.). Res. J. of Agric. and Biol. Sci., 5(2):161-166.

Estiken, A. and M.Turan (2004). Alternating magnetic field effects on yield and plant nutrient element composition of strawberry (Fragariax ananassa cv. Camarosa). Soil and plant Sci., 54 (3):135-139. 
Hajer, A.S; A.A. Malibari; H.S. Al-Zahrani and O.A. Almaghrab (2006). Responses of three tomato cultivars to sea water salinity 1.Effect of salinity on the seedling growth. Afric. J. of biotech., 5 (10) 1684-5315

Hameda , E. A. (2014). Impact of Magnetic Water Irrigation for Improve the Growth, Chemical Composition and Yield Production of Broad Bean (Vicia faba L.) Plant. Amer. J. of Exper. Agr., 4 (4): 476-496.

Helal Ragab Mousa (2011). The impact of magnetic water application for improving common bean (Phaseolus vulgaris L.) production. New York Sci. Jour. 4(6) 15-20.

Hilal, M. and M. Hilal (2000). Application of magnetic technologies in desert agriculture. 1-Seed germination and seedling emergence of some crops in a saline calcareous soil. Egyptian J. of soil Science, 40(3): 413-422.

Hozayn M., Abd Elmonem A. A., Abdelraouf R. E. and M. M. Abdalla (2013). Do magnetic water affect water use efficiency, quality and yield of sugar beet (Beta vulgaris L.) plant under arid regions conditions? J. of Agronomy, 12 (1): 1-10.

Hozayn M. and Amira Mohamed Saeed Abdul Qados. (2010). Irrigation with magnetized water enhances growth, chemical constituent and yield of chickpea (Cicer arietinum L.). Agric. Biol. J., 1 (4): 671-676.

James, C. S. (1995). Analytical chemistry of foods Blockier Academic, professional, London.

Jensen, M.E. (1983). Design and operation of farm irrigation systems. Amer. Soc. Agric. Eng. Michigan, USA, p. 827.

Khazan, M. M. and Abdullatif, B. M. (2009). Effect of irrigation with magnetized water on growth, photosynthesis pigments and proline accumulation in jojoba plants (Simmondsia chinesis L.) seedlings. Saudi J. Biol. Sci., 16 (3): 107-113.

Mahdi I. Aoda (2011). The interactive effects of water magnetic treatment and deficit irrigation on plant productivity and water use efficiency on corn (Zea mays L.). Iraqi J. of Agric. Sci. vol 42:2 (abstract).

Maheshwari, B.L. and H.S. Grewal (2009). Magnetic treatment of irrigation water: Its effects on vegetable crop yield and water productivity. Agric. Water Manage, 96 (8): 1229-1236.

Mohamed, A.I. and B.M. Ebead (2013). Effect of magnetic treated irrigation water on salt removal from $A$ sandy soil and on the Availability of certain nutrients. International J. of Engineering, 2(2): P, 2305-8269

Morejon, L.P.; Castro J.C.; Velazquez L.G. and A.P. Govea (2007). Simulation of Pinus tropicalis M. seeds by magnetically treated water. Int Agrophys. 21:173-177.

Moussa, H.R. (2011). The impact magnetic water application for improving common bean (Phaseolus vulgaris L.) production. New York Science J., 4 (6): 15-20.

Mulook, Al-Khazan, Batoul M. Abdullatif and A. Nabila (2011). Effects of magnetically treated water on water status, chlorophyll pigments and some elements content of Jojoba (Simmondsia chinensis L.) at different growth stages. Afr. J. Environ. Sci. Technol., 5 (9): 722-731. 
Mrunal Deshpande (2014). Effect of magnetic water on growth of Legumes. European J. of Applied Engineering and Scientific Research., 3 (3): 912.

Osman, E.A. M., K.M Abd El-Latif, S.M. Hussien and A.E.A. Sherif, (2014). Assessing the effect of irrigation with different levels of saline magnetic water on growth parameters and mineral contents of pear seedlings. Glob J. Sci. Res., 2 (5): 128-136.

Ozeki, S. and I. Otsuka (2006). Transient oxygen clothes rate-like hydrate and water networks induced by magnetic field. J. Phys. Chem., 110: 2067-2072.

Pregl, E. (1945). Quantitative organic micro analysis 4th ed. J. Chun drill, London.

Sadeghipour O. and P.Aghaei (2013). Improving the growth of cowpea (Vigna unguiculata L.) by magnetized water. J. Bio. Envoi. Sci. 3 (1): 37-43.

Trough, E. and Meyer (1939). Improvement in denies calorimetric method for phosphorus and arsenic. Indian English Chemistry Analysis Edition. 1:136- 139.

Waller, R.A. and D. B. Duncan (1969). A basic rule for the symmetric multiple comparison problem. Amer.Statis.Assoc.J.12:1485-1503.

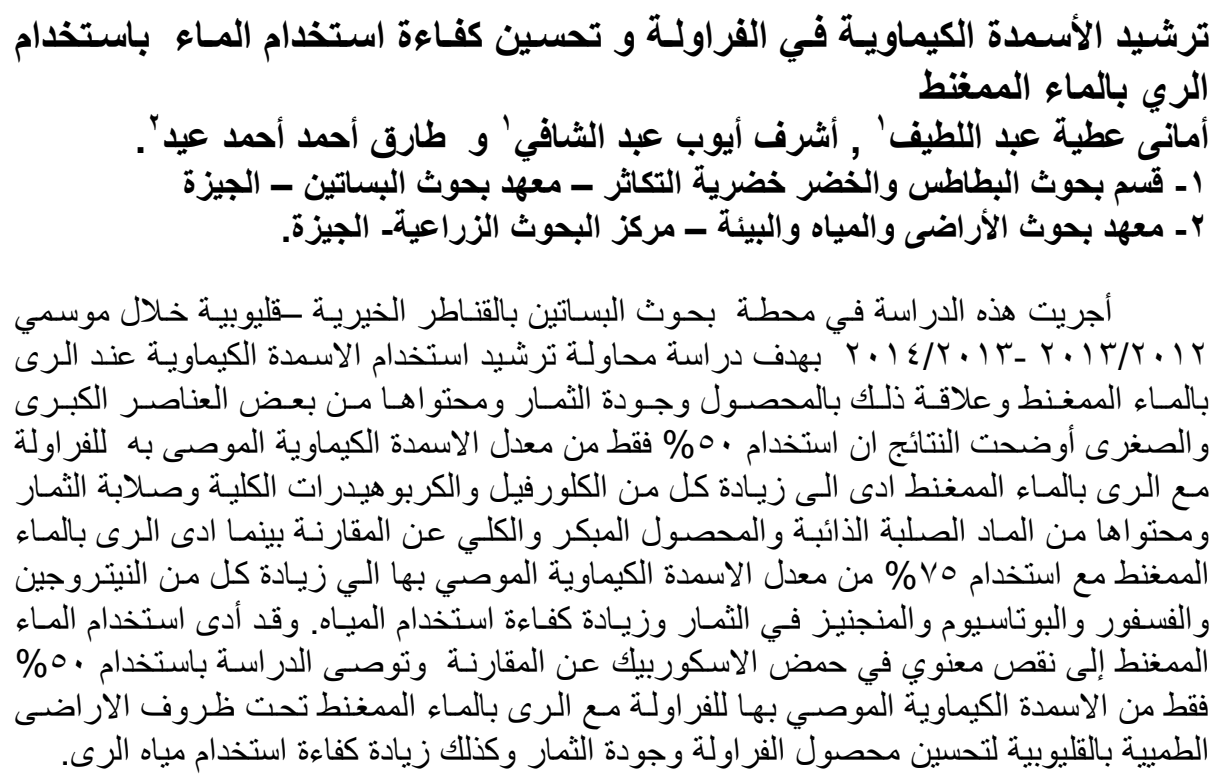

